APA Bilgiç, ì., Pirdal, B. (2021). EKONOMi POLiTiKASI PERSPEKTiFINDEN VERGiLEMENIN ÖNEMi: OPEC ÜYESI ORTADOĞU ÜLKELERi ÖRNEĞi. Anadolu Üniversitesi İktisadi ve İdari Bilimler Fakültesi Dergisi, 22 (2), 73-82.

DOI 10.53443/anadoluibfd.952745

Araştırma Makalesi

Başvuru Tarihi: 15.06.2021

Kabul Tarihi: 29.06.2021
Research Article

Date Submitted: 15.06.2021

Date Accepted: 29.06.2021

\title{
EKONOMI POLITIKASI PERSPEKTIFINDEN VERGILEMENIN ÖNEMI: OPEC ÜYESI ORTADOĞU ÜLKELERI ÖRNEĞi
}

\author{
Ibrahim Bilgiç ${ }^{1}$ \\ Araş. Gör. Burak Pirdal²
}

\section{ÖZET}

\begin{abstract}
Anahtar
Kelimeler:

Devletler kamu harcamamalarının finansmanı için kamu gelirlerine ihtiyaç duyar. Vergiler ise birçok devlet için geçmişten günümüze en önemli kamu gelirlerinden biri olagelmiştir. Ancak, petrol zengini orta doğu ülkelerinin genelinde olduğu gibi

* Vergi,

* Vergileme,

* Vergi Politikası,

* Ekonomi Politikası,

* OPEC Ülkeleri. pek çok devlet açısından bu kamu geliri öncelik arz etmemektedir. Bu durum ise ekonomi politikaları açısından bir takım arzu edilmeyen sonuçlara gebe olabilir. Bu çalışmada vergilemenin ekonomi politikası açısından önemi OPEC üyesi Ortadoğu ülkeleri örneği çerçevesinde ele alınmıştır. Vergi gelirlerinin göreli önemsizliği ve vergileme sisteminin görece gelişmemiş olması durumları bu ülkelerde ekonomi politikalarının etkinliğini baltalamaktadır. İncelenen ülkelerin vergi ve vergileme alanlarında gerçekleştirebileceği olası reformların, sağlayabilecek olduğu potansiyel katma değer açısından kilit önemi haizdir.
\end{abstract}

\section{THE IMPORTANCE OF TAXATION FROM THE PERSPECTIVE OF ECONOMIC POLICY: THE CASE OF OPEC MEMBER MIDDLE EASTERN COUNTRIES}

İbrahim Bilgiç

Res. Asst. Burak Pirdal

ABSTRACT
Governments need public revenues in order to fund public expenditures. From past to present. taxes have been one of the most important public revenues for many governments. However, this public income is not a priority for many states, as is the case in oil-rich Middle Eastern countries. This situation may have some undesirable consequences in terms of economic policies. In this study, the importance of taxation in terms of economic policy is discussed within the framework of the example of OPEC member Middle East countries. The relative insignificance of tax revenues and the relatively undeveloped taxation system undermine the effectiveness of economic policies in these countries. It is of key importance in terms of the potential added value that the possible

Keywords:

* Tax,

* Taxation,

* Tax Policy,

* Economic Policy,

* OPEC Countries. reforms that the examined countries can realize in the fields of tax and taxation.

${ }^{1}$ İstanbul Aydın Üniversitesi SBE Yüksek Lisans Öğrencisi, e-mail: ibrahimbilgic@stu.aydin.edu.tr, Orcid: https://orcid.org/0000-0002-2343-0690.

${ }^{2}$ Anadolu Üniversitesi, iïBF, Maliye Bölümü, e-mail: burakpirdal@anadolu.edu.tr, Orcid: https://orcid.org/00000002-7856-5701. 


\section{GiRiş}

Makroekonomik dinamiklerde arzu edilen değişikliklerin gerçekleştirilmesine dönük uygulanacak olan önlemler paketine şemsiye bir kavram olarak 'ekonomi politikası' denir (Eğilmez \& Kumcu, 2015). Dolayısıyla, ekonomi politikaları makroekonomik değişkenlerin etkilenmesi/dizayn edilmesi suretiyle ekonominin bir bütün olarak istenilen yönde şekillendirilmesi çabalarını içerir. Ekonomi politikasının bileşenlerinden biri de 'vergi politikası'dır.

Vergi, günümüz modern devletleri açısından en önemli kamu gelirlerinden biridir ve vergi sisteminin iyi işlemesi ile ekonomi politikasının etkinliği arasında güçlü bir ilişki mevcuttur. Etkin bir vergi politikası ve iyi işleyen bir vergileme süreci ile devletler, makroekonomik dinamiklerin önemli bir kısmını arzu edilen doğrultuda etkileyebilme/yönlendirebilme konusunda güçlenirler. Nitekim iktisatçılar açısından, vergiler ve vergilerin tahsilatına dönük politikalar, yalnızca birtakım yasal zorunlulukların kabulü ve icrasından fazlasını ifade eder.

Bir ülke açısından, etkin bir vergi sisteminin yokluğu, önemli bir maliye politikası aracından mahrumiyeti temsil eder. Bu durum devletlerin etkin ve bağımsız bir maliye politikası uygulayabilme kapasitesini sınırlandırma anlamında ekonomi politikalarının potansiyel etkinliğini de baltalar. Nitekim ekonomi politikaları oluşturulurken dikkat edilmesi gereken en önemli unsurlardan biri de politika araçlarının sayısı ile politika hedeflerinin sayısı arasındaki uyumdur ${ }^{3}$ (Tinbergen, 1952).

$\mathrm{Bu}$ çalışmanın amacı vergi ve vergileme kavramlarının ekonomi politikası açısından öneminin OPEC üyesi Orta Doğu ülkeleri örneği temelinde araştırılması ve konuya ilişkin politika önerilerinde bulunulmasıdır.

\footnotetext{
${ }^{3}$ Ayrıca bkz. 'Tinbergen Kuralı' ('Tinbergen Rule').
}

Bu anlamda, bu çalışmanın araştırma soruları şunlardır: (i) Vergi ve vergileme kavramlarının ekonomi politikalarının etkinliği açısından önemi nedir? (ii) Vergi ve vergileme sistemlerinin yeterince gelişmemiş olmasının makroekonomik anlamda ne gibi sonuçları olabilir? (iii) OPEC üyesi Orta Doğu ülkelerinde vergi ve vergileme sistemlerinin önemi bu ülkelerin ekonomileri açısından ne düzeydedir? (iv) OPEC üyesi Orta Doğu ülkelerinde vergi ve vergileme sistemlerinin mevcut yapısı ne gibi sonuçlara yol açmış ve açacaktır? (v) Bu ülkelerin vergi politikası anlamında ne gibi önlemler almaları gerekmektedir?

$\mathrm{Bu}$ araştırma sorularına; konuya ilişkin teori ve güncel verilerden de yararlanılması suretiyle betimsel analiz yöntemi ile yanıt aranmıştır.

Çalışmanın geri kalanında öncelikle vergi, vergileme ve ekonomi politikası gibi temel kavramlar ile bu kavramların birbirleri ile olan etkileşimleri üzerinde durulmuştur. Akabinde ise OPEC üyesi Orta Doğu ülkeleri; vergi sistemi, vergileme, vergi politikası ve ekonomi politikası açısından incelenmiş, konuya ilişkin olarak politika önerilerinde bulunulmuştur.

\section{VERGI VE VERGILEME KAVRAMLARI}

Devletler kamu harcamamalarının finansmanı için kamu gelirlerine ihtiyaç duyar. Vergiler ise birçok devlet için geçmişten günümüze en önemli kamu gelirlerinden biri olagelmiştir. Nitekim vergilerin öncelikli amacı devletin gelir elde etmesidir. Bu doğrultuda, vergiler hem önemli miktarlarda kamu geliri sağlama hem de devlet egemenliğinin varlığının bir sonucu/yansıması olma anlamında kamu gelirleri arasında ayrıcalıklı bir konuma sahiptir. 
Günümüz dünyasında birçok ulusal ekonomi yetersiz seviyelerdeki kamu gelirleri ve her geçen gün artış gösteren kamu harcamaları ile karşı karşıyadır. Devletlerin çeşitli mali zorluklarla baş etmek durumunda olduğu böylesi bir atmosferde kamu gelirlerinin arttırılması, vergilerin en önemli işlevi olmaya devam etmektedir (OECD, 2014: 30). Bunun dışında, vergiler; başkaca bir takım iktisadi ve/veya sosyal amaçlar çerçevesinde de kullanılmaktadır.

Vergi kavramının literatürde birçok tanımı olmakla birlikte bu tanımlar önemli sayılabilecek herhangi bir farklııı arz etmemekte, büyük ölçüde paralellik sergilemektedir. 'Vergi' kavramı basitçe, ekonomik değerlerin özel ekonomiden kamu ekonomisine tek taraflı, kesin ve nihai olarak aktarılması şeklinde tanımlanabilir. Henry Laufenburger ise vergi kavramını kamu harcamalarına mutlak ve zorunlu bir katılım olarak tanımlamaktadır (Gökçe, 2006: 4). Tekir (1993)'e göre ise vergi, devletlerin kamu harcamalarını finanse etmek amacıyla, egemenlik gücüne dayalı olarak ve herhangi bir özel yarar vaat etmeksizin gerçek ve tüzel kişilerden almış olduğu ekonomik değerlerdir. Şen \& Sağbaş (2016) ise vergi kavramını 'gerçek ve/veya tüzel kişilerden ve de tüzel kişi olma özelliği bulunmayan bir takım kurum ve kuruluşlardan hukuki cebir temelinde elde edilen ekonomik değerler' olarak tanımlamaktadır.

Bu bağlamda, vergi; devletin başta kamu giderlerini karşılamak üzere tabiiyet ve/veya yersellik ilkeleri doğrultusunda gerçek ve/veya tüzel kişilerden mali güçleri nispetinde cebren, yasalara dayalı ve de karşılıksız olarak alınan iktisadi değerlerdir. Devletler bu ekonomik kıymetleri bir takım mali/mali olmayan amaçların ifası niyeti ile egemenlik gücü temelinde toplar. $\mathrm{Ne}$ şekilde ve kim(ler) tarafından tanımlanmış olması dikkate alınmaksızın, vergi kavramı, her daim (i) özellikle kamu harcamalarının finansmanı amacı ile toplanma, (ii) özel bir karşılığı bulunmama ve (iii) hukuki anlamda cebirsel olma özelliklerini haizdir (Şen ve Sağbaş, 2016).

4 Cebire başvurma yetkisi, devletlerin egemenlik gücünden kaynaklanmaktadır.
Bahsi geçen tanımlamalar ve açıklamalardan yola çıkılarak vergi kavramının ana unsurları tespit edilebilir. Bu kapsamda, verginin temel unsurları şunlardır: (i) herhangi bir hizmetin ifasıyla değil, genellikle nakit olarak ödenmesi, (ii) öncelikli olarak kamu harcamalarının finansmanı amacıyla toplanması, (iii) mükellefler için yasal bir zorunluluk (hukuki cebir unsuru) bulunması, (iv) Herhangi bir mal(lar)ın veya hizmet(ler)in bire bir karşılığı anlamını ihtiva etmemesi, (v) devlet görevlilerinin keyfiyetine göre değil, bir takım yasal prosedürlere toplanması.

Sonuç olarak; vergi, devletlerin gerçek ve/veya tüzel kişilerden cebren ${ }^{4}$ ve bedelsiz olarak almış olduğu ekonomik değerler olarak tanımlanabilir.

Vergiler, günümüzde çoğu devlet için en önemli kamu geliri olma özelliğindedir. Bu nedenle, devletlerin sağlam bir kamu mali yönetime sahip olmaları ile etkin şekilde işleyen bir vergi sistemine sahip olmaları yakinen alakalıdır. Öte yandan, vergiler birçok ülke için yalnızca önemli bir kamu geliri kalemi olmaktan ziyade, aynı zamanda bir tür makroekonomik politika aracıdır. Etkin bir vergi politikası ve de iyi yönetilen bir vergilendirme sürecinin eşanlı mevcudiyetinin söz konusu olması durumunda devletler makroekonomik dinamiklerin çoğunu arzu edilen yönde şekillendirebilme konusunda güçlenirler. Diğer yandan, iyi işleyen bir kamu mali yönetimi; kalkınma, ekonomik büyüme ve diğer birçok makroekonomik dinamik açısından temel ve belirleyici bir faktör olabilir. Böylesi bir politika, devletlere; bütçe açıklarını azaltma, etkin bir borç yönetimini sağlama ve mali performansı arttırma gibi kanallar vasıtası ile krizlerin üstesinden gelinmesi hususunda da destek olabilme potansiyeline sahiptir (Üyümez vd., 2020: 201).

'Vergileme' ise vergilerin gerçek ve tüzel kişilerden devletler tarafından cebren toplanması işlemidir (Neumark, 2020). Bu kavram; devletler açısından vergi toplanmasını, mükellefler açısından 
ise vergi verilmesini ifade eder. Dolayısıyla, devlet ile vergi mükellefleri arasında bir borç-alacak ilişkisi doğurur ve vergi politikasının başarısında belirleyici faktörlerdendir (Şen \& Sağbaş, 2017: 119).

\section{EKONOMI POLITIKASI}

Devletler ekonomik anlamda arzu edilen hedeflerin gerçekleştirilmesi için çeşitli politikalar uygulayabilirler. Bu politikalar makroekonomik bir yaklaşımı ifade eder. Nitekim makroekonomi alanında ekonomi bir bütün olarak incelenir (Mankiw, 2003: 13). Enflasyon, ekonomik büyüme, işsizlik, milli gelir gibi kavramlar ise günlük hayatta sıkça karşılaşılan ve her bir bireyi yakından ilgilendiren makroekonomik unsurlardır.

Bu anlamda, 'ekonomi politikası' kavramı makroekonomik ${ }^{5}$ bir ifadedir ve en basit haliyle 'makroekonomik dengelerin nasıl ve hangi yönde değiştirileceğine ilişkin yaklaşımları kapsayan dal' olarak tanımlanır. Diğer bir ifadeyle, makroekonomik dinamiklerde arzu edilen değişikliklerin gerçekleştirilmesine dönük uygulanacak olan önlemler paketine şemsiye bir kavram olarak 'ekonomi politikası' denir (Eğilmez \& Kumcu, 2015).

Ekonomi politikaları vasıtası ile bir takım makroekonomik hedeflerin gerçekleştirilmesi amaçlanır. En temel makroekonomik hedeflerden biri de makroekonomik istikrardır ve bu kavram fiyatlar genel düzeyindeki istikrar ile tam istihdamın eş anlı mevcudiyeti anlamına gelir (Türk, 1989: 73; aktaran Akan, vd: 109). Ekonomi politikası ise temelde makroekonomik dengesizlikleri (istikrarsılıkları) giderecek olan tedbirlerin alınmasını ve uygulanmasını öngörür. Bunula birlikte, ekonomik dengelerde herhangi bir bozulmanın/istikrarsızlığın söz konusu olmadığı durumlarda dahi daha iyi bir makroekonomik dengeye ulaşılabilmesi amacıyla da ekonomi

5 'Ekonomi’ kavramı iktisat literatüründe genel anlamda 'makroekonomi' ve 'mikroekonomi' olarak ikili bir ayrıma tabi tutulur. Makroekonomi, ekonomiyi bir bütün olarak inceler. Bu sebeple; gelirlerdeki artış, fiyatlardaki değişimler ve işsizlik oranları gibi dinamikler politikalarına başvurulabilir. Söz konusu durumda ise ekonomi politikaları, mevcut ekonomik dengede istenilen yönde değişiklik yapılabilmesine yönelik alınması gereken önlemleri içerir (Eğilmez ve Kumcu, 2015).

Ekonomi politikasının ana bileşenlerinden biri maliye politikasıdır. Bu politikanın icra edilmesinde başvurulan kamu harcamaları, kamu gelirleri ve borçlanma gibi unsurlara ise mali araçlar ya da maliye politikası araçları denir. Dolayısıyla, söz konusu mali araçlarının kullanılması suretiyle ekonomik hedeflere ulaşılmasını amaçlayan uygulamalar bütününe 'maliye politikası' denir. Maliye politikası; ekonomik büyüme, denk bütçe, ekonomik istikrar, yüksek istihdam oranları, sürdürülebilir cari denge, iç ve dış finansmanın dengeli bir şekilde yönetilmesi, tasarruf ve yatırımların artırılması, gelir dağılımının iyileştirilmesi amaçlarına yönelik kullanılabilir (Eğilmez ve Kumcu, 2015). Örneğin, bir ülkede kamu harcamalarındaki ve/veya vergi düzeylerindeki değişimler mal ve hizmet üretimine olan talebi, ulusal tasarrufu, yatırım düzeyini ve denge faiz oranını değiştirebilir (Mankiw, 2003: 61).

Bununla birlikte, maliye politikasının bileşenlerinden (alt politikalarından) biri ise 'vergi politikası'dır. Vergi politikası, başta vergiler olmak üzere kamu gelirlerinin kapsamının, oranının ve/veya miktarının değiştirilmesi suretiyle ekonominin yönlendirilmesi amacını haiz politikalar bütünüdür (Eğilmez ve Kumcu, 2015). Nitekim vergi politikaları; tasarruf ve yatırım oranında ve dolayısıyla büyüme oranlarında değişikliklere yol açabilir (Musgrave \& Musgrave, 1989: 236).

makroekonomiyi ilgilendirir. Mikroekonomi ise temelde hanehalklarının ve firmaların nasıl karar verdiğini ve bu karar birimlerinin piyasada nasıl etkileşime girdiğini inceler (Mankiw, 2003: 12-14). 


\section{EKONOMI POLITIKASI PERSPEKTIFINDEN VERGI VE VERGILEME}

Vergilerin öncelikli amacı devletlere kamu harcamalarının finansmanı için kamu geliri sağlanmasıdır. Bununla birlikte, vergiler bazı makroekonomik hedeflerin gerçekleştirilmesine yönelik olarak etkin bir araç olabilir. Bu bağlamda, vergiler büyüme, kalkınma, bölgesel/sektörel gelişmişlik farklarının en aza indirilmesi, gelir/servet dağılımında adalet, kaynak dağılımında etkinlik ve makroekonomik istikrar gibi politika hedefleri bağlamında başvurulabilecek olan bir mali araçtır (Şen \& Sağbaş, 2017: 386).

Vergi politikaları bir ekonomiyi temel olarak mal ve hizmetlere olan talep düzeyini; çalışma, tasarruf ve yatııım kararlarını ve de bütçe açıklarının miktarını değiştirerek etkiler. Örneğin, vergi politikası bir ülke dahilindeki bölgesel ekonomik kalkınma düzeylerindeki farklılıkların ve yatırımların dengesiz dağılımının düzenlenmesi gibi konularda etkin bir araç olarak kullanılabilir.

Bir ülke açısından, etkin bir vergi sisteminin yokluğu önemli bir maliye politikası aracından mahrumiyeti temsil eder. Bu durum devletlerin etkin ve bağımsız bir maliye politikası uygulayabilme kapasitesini sınırlandırma anlamında ekonomi politikalarının potansiyel etkinliğini de baltalar. Nitekim ekonomi politikaları oluşturulurken dikkat edilmesi gereken en önemli unsurlardan biri de politika araçlarının sayısı ile politika hedeflerinin sayısı arasındaki uyumdur.

$\mathrm{Bu}$ bağlamda, Tinbergen (1952) bir ekonomide politika hedeflerinin başarılı bir şekilde uygulanabilmesi için mevcut politika hedeflerinin sayısına eşit sayıda politika aracının varlığının gerekli olduğunu belirtmiştir. Bu, uygulanacak her bir politika hedefi için en az bir politika aracının varlığını gerektirir ve bu görüşe literatürde "Tinbergen Kuralı" 6 denir.

\footnotetext{
${ }^{6}$ Bkz. 'Tinbergen rule'.
}

Diğer yandan, vergiler ile kalkınmaya dönük ekonomi politikaları arasında da güçlü bir ilişki mevcuttur. Vergiler yoluyla ekonomik büyüme ve kalkınma temelde iki farkı kanalla sağlanır: (i) devletlerin toplanan vergileri kamu harcamamaları olarak büyüme ve kalkınma amaçlarına dönük kullanması, (ii) vergiler vasıtası ile elde edilen gelirin kullanımı ile beşerî sermayeye yönelik olarak kalkınma carilerine ${ }^{7}$ yapılan harcamaların arttırıması (Şen \& Sağbaş, 2017: 377). Bu kanallardan ilki fiziki altyapı yatırımlarını ifade ederken ikincisi ise beşerî sermayeye vurgu yapar.

Kalkınma ve büyüme ile sanayileşme faktörü de yakından ilişkilidir. Sanayinin gelişmesi için uygun bir fiziki altyapının mevcudiyeti esastır. Zira iyi bir fiziki altyapı olmaksızın sanayinin gelişmesi ve üretim faaliyetlerinin etkin şekilde icrası kabil değildir. Bu anlamda, ulaştırma ve haberleşme gibi altyapı yatırımları hem devletlerin esas görevlerinden ve hem de kalkınmanın itici faktörlerindendir. Bununla birlikte, kalkınma yalnızca fiziki altyapı ile değil, insan unsuru, diğer bir ifadeyle beşerî sermaye ile de yakından ilişkilidir. Bu ise yatırım carilerine yönelik ayrılan kaynakların ve böylece insan gücünün niteliksel gelişiminin göreli önemini vurgulamaktadır.

Kamu harcamalarının yanı sıra kamu sektörünün ekonomik kalkınmayı teşvik etmek için uygun gördüğü yatırım harcamalarının finanse edilebilmesi için de vergilere intiyaç duyulur. Vergiler bir toplumun tasarruflarını harekete geçirmek ve onları gelecek vaat eden yatırım beklentilerine yönlendirebilmek için etkin bir şekilde kullanılabilir. Bu işlev herhangi bir toplumda belli düzeyde önem arz edebilir, ancak sermaye piyasalarının olgunlaşmamış olduğu az gelişmiş ülkelerde özellikle önemlidir. Vergiler ayrıca özellikle de gelir dağılımının adaletsiz olduğu ülkelerde gelir dağılımının iyileştirilmesi amacına yönelik olarak etkili ve oldukça hızı sonuç doğuran bir mali araç olabilir. Etkin şekilde tasarlanmış olan ve iyi yönetilen vergileme mekanizmaları, özel sektörün ve de bir bütün olarak ulusal ekonominin

\footnotetext{
${ }^{7}$ Eğitim ve sağlık harcamalarına 'kalkınma carileri' ya da 'yatırım carileri' de denir.
} 
uzun vadede topluma faydalı olacağı düşünülen yönlerde desteklenmesi edilmesi amacıyla kullanılabilir (Askari et al, 1982: 3).

\section{OPEC ÜYESI ORTA DOĞU ÜLKELERINDE EKONOMI POLITIKALARI VE VERGILEME}

Petrol İhraç Eden Ülkeler Örgütü (Organization of Petroleum Exporting CountriesOPEC), 10-14 Eylül 1960'ta düzenlenen Bağdat Konferansı'nda İran İslam Cumhuriyeti, Irak Cumhuriyeti, Kuveyt Devleti, Suudi Arabistan Krallığı ve Bolivarcı Venezuela Cumhuriyeti'nden oluşan ${ }^{8}$ beş ülke tarafından kurulan devletler arası bir oluşumdur. 2021 yılı itibariyle örgütün toplam 13 üyesi bulunmaktadır ${ }^{9}$ (OPEC, 2021a).

OPEC üyesi ülkelerden beşi Ortadoğu ülkesidir: İran, Irak, Kuveyt, Suudi Arabistan ve Birleşik Arap Emirlikleri. 2018 yılı itibarıyla OPEC üyesi ülkelerin dünya ham petrol rezervlerindeki payı \%79.4 olmakla birlikte toplam OPEC petrol rezervlerinin \%64.5'i ise OPEC üyesi Orta Doğu ülkelerine aittir (OPEC, 2021b).

Yaygın olarak "Petrol Zengini Arap Ülkeleri" olarak da adlandırılan OPEC üyesi Orta Doğu ülkeleri için, ekonominin petrol gelirlerine yüksek oranda bağımlı olması karakteristik bir özelliktir. Aşağıda yer alan Tablo 1 OPEC üyesi Orta Doğu ülkelerinde petrol ihracatından elde edilen gelirin bu ülkelerin GSYiH'sına oranını göstermektedir.
Tablo 1: Petrol İhracatının (Milyon ABD Doları) Piyasa Fiyatları ile GSYiH'ya Oranı (Milyon ABD Doları), (Yüzde Oran): 2019

\begin{tabular}{|l|l|}
\hline IRAN & 0.04 \\
\hline IRAK & 0.30 \\
\hline KUVEYT & 0.39 \\
\hline SUUDI ARABISTAN & 0.25 \\
\hline $\begin{array}{l}\text { BIRLEŞiK ARAP } \\
\text { EMIRLIKLERI }\end{array}$ & 0.11 \\
\hline ORTALAMA & 0.22 \\
\hline
\end{tabular}

Kaynak: OPEC.

Yukarıdaki Tablo 1'de yer alan verilere istinaden; İran dışındaki ekonomilerin petrole bağımlılığının oldukça yüksek seviyelerde olduğu gözlemlenmektedir. Örneğin, Kuveyt'in GSYiH'sının yaklaşık \%40'ı petrol ihracatından elde edilen gelirlerinden oluşmaktadır. Benzer şekilde; Irak, Katar ve Suudi Arabistan için ise bu oran sırasıyla $\% 30, \% 25$ ve $\% 11$ 'dir.

Petrol gelirlerine olan yüksek derecede bağımlılık, bu ekonomilerin kırılganlık derecesini artırıcı bir faktör olarak birçok dezavantajı beraberinde getirmektedir. Bu ülkeler, petrol gelirlerinde meydana gelen değişikliklerden (artış veya azalış) kaynaklı olarak ekonomik istikrarsızlıklar yaşamaktadır. Bunun temel nedeni, petrol fiyatlarının küresel/bölgesel krizler, politik istikrarsızlıklar, her nevi toplumsal çalkantı ve/veya benzeri nitelikteki diğer beklenmedik gelişmelere karşı duyarlılığının yüksek olmasıdır.

Diğer yandan, bu ülkelerde vergi gelirleri de görece oldukça düşük seviyelerdedir. Bu bağlamda, aşağıda yer alan Tablo 2, 2018 yılında OPEC üyesi orta doğu ülkelerinde vergi gelirleri/GSYiH oranlarını yansıtmaktadır.

9 OPEC üyeleri İran, Irak, Kuveyt, Suudi Arabistan, Venezuela, Libya, Birleşik Arap Emirlikleri, Cezayir, Nijerya, Gabon, Angola, Ekvator Ginesi ve Kongo'dan oluşur.

\footnotetext{
${ }^{8} \mathrm{Bu}$ isimler bu ülkelerin resmi isimleridir. Bu ülkeler yaygın olarak sırasıyla İran, Irak, Kuveyt, Suudi Arabistan ve Venezuela olarak bilinir.
} 
Tablo 2: OPEC Üyesi Orta Doğu Ülkelerinde Vergi Gelirlerinin GSYiH'ya Oranı (Yüzde Oran): 2018

\begin{tabular}{|l|c|}
\hline IRAN & 6.7 \\
\hline IRAK & 1.8 \\
\hline KUVEYT & 1.5 \\
\hline SUUDI ARABISTAN & 4.7 \\
\hline BIRLEŞIK ARAP EMIRLIKLERI & 15.8 \\
\hline ORTALAMA & 5.8 \\
\hline
\end{tabular}

Kaynak: IMF.

Tablo 2'de yer alan verilere göre, bu ülkelerde vergi gelirlerinin GSYiH'ya oranı, gelişmiş ekonomilere ve/veya OECD ülkeleri ortalamasına göre oldukça düşük seviyelerdedir. Bu anlamda, 2018 yılında Amerika Birleşik Devletleri (ABD), Almanya, Japonya, Birleşik Krallık (İngiltere) ve Fransa gibi gelişmiş ekonomiler için vergi gelirlerinin GSYIH'ya oranı sırasıyla \%24.4, \%38.5, $\% 32, \% 32.8$ ve $\% 46$ olarak gerçekleşmiştir. Öte yandan, bu oranın OECD üyesi ülkeler için aynı yıl ortalaması ise \%33.84'tür (OECD, 2021).

İran'da petrol ve doğal gaz ihracatından elde edilen gelirler, dünya petrol piyasalarındaki dalgalanmalara göre değişmekle birlikte, kamu gelirleri içerisinde en büyük paya sahiptir. Bununla birlikte, İran ekonomisinin petrol gelirlerinin incelenen diğer ülkelere nispeten düşük seviyelerde olmasının temel nedenlerinden biri İran hükümetinin uranyum zenginleştirme programı sebebiyle bu ülkeye uygulanan uluslararası ekonomik yaptırımlardır. Bu koşullar, İran'ın petrol ve türev ürünleri ihracatını zorlaştırmak suretiyle ülke ekonomisinin diğer incelenen ülkelere kıyasla petrol gelirlerine daha az bağımlı olması sonucunun sebeplerinden biridir.

Öte yandan İran ekonomisi, devletçi ekonomi politikalarının hâkim olduğu ve bir ölçüde petrol ve gaz ihracatına bağımlı olmasına rağmen; önemli tarım, sanayi ve hizmet sektörlerine de sahiptir. İran hükümeti, çoğu ülkenin güvenlik güçleri tarafından dolaylı olarak kontrol edilmekte

${ }^{10}$ World Trade Organization (WTO). olan yüzlerce kamu işletmesinin doğrudan sahibi ve işletmecisidir. İran'da kayıt dışı ekonominin boyutları da nispeten yüksektir.

Incelenen diğer ülkelerde ise ulusal ekonominin petrol gelirlerine bağımlılı̆̆ İran ekonomisine nazaran oldukça yüksek seviyelerdedir. Örneğin, 2019 yılı verilerine göre Irak'ın petrol ürünleri ihracatından elde ettiği gelirin toplam ihracat gelirleri içerisindeki payı \%97.5 iken petrol ihracatı gelirlerinin GSYIH'ya oranı ise aynı yıl için \%30 olarak gerçekleşmiştir. Bu oranlar aynı yıl için Kuveyt'te ise sırasıyla \%72 ve \%39'dur. Suudi Arabistan'da da durum benzerdir: 2019 yılında Suudi Arabistan ekonomisinin yaklaşık dörtte biri petrol ihracatı gelirlerinden meydana gelmiştir (OPEC, 2021d). Bununla birlikte Suudi Arabistan hükümeti ekonominin petrole bağımlılığının azaltılması amacına dönük birtakım girişimlerde bulunmaktadır.

Suudi Arabistan, dünyada lider petrol ve doğal gaz üreticilerindendir. Suud hükümeti, özellikle Suudi Arabistan'ın Aralık 2005'te Dünya Ticaret Örgütü'ne ${ }^{10}$ katılımından bu yana ekonomik reform ve çeşitlendirmeyi sürdürmeye çalışmakta ve de yabancı yatırımı teşvik etmek için birtakım önlemler almaktadır. Artan nüfus, önemli doğal kaynakların azalması ve ulusal ekonominin büyük ölçüde petrol üretimine ve petrol fiyatlarına bağımlı olması ise Suudi Arabistan açısından temel ekonomik ve siyasi endişe kaynaklarıdır.

Nisan 2016'da Suudi Arabistan; petrole olan ekonomik bağımlılı̆ını azaltmak, ekonomiyi çeşitlendirmek ve sağlık, eğitim, fiziki altyapı yatırımları, rekreasyon ve turizm gibi hizmet sektörlerini iyileştirmek amacıyla 'Plan Vizyon $2030^{\prime}$ u tasarlamış ve kabul etmiştir. Hem Plan Vizyon 2030'da hem de Ulusal Dönüşüm Planı'nda ana hatlarıyla belirtilen bir dizi kapsamlı reformun çeşitli alanlar için bazı potansiyel sonuçları mevcuttur. Ayrıca, kamu gelirlerinin petrole bağımlılığını azaltma ve daha geniş kapsamlı sosoekonomik hedeflere ulaşma çabalarının bir parçası olarak vergi politikaları da bu reformlarda önemli 
bir rol oynamaktadır. Bu anlamda, örneğin, Plan Vizyon 2030'un ana hedeflerinden biri, 2030 yılına kadar doğrudan yabancı yatırımları GSYiH'sının $\% 3,8$ 'inden \%5,7'sine çıkarmaktır. Bu amaç doğrultusunda Suudi Arabistan, çifte vergilendirme anlaşmalarını yabancı yatırımcıları ülkeye çekmenin önemli bir yolu olarak görmektedir. Bu politika ile Suudi Arabistan temel olarak yabancı yatırımcılara gelirin çifte vergilendirilmenin söz konusu olmayacağı güvencesini vermeyi amaçlamaktadır. Çifte vergilendirme anlaşmaları yerel vergi kurallarını geçersiz kılar ve Birleşik Krallık, Çin, İsviçre ve Japonya dahil olmak üzere bir dizi ülke ile imzalanmıştır (PWC, 2021).

\section{POLITIKA ÖNERISI}

Vergilerin asli amacı kamu devletlerin geliri elde etmesidir. Bu çalışma dahilinde incelenen ülkelerde vergi gelirlerinin toplam kamu gelirleri içerisindeki payının görece düşük olması onları önemli boyutlarda potansiyel bir kamu gelirinden mahrum bırakmaktadır. Bu ise bir yandan kamu gelirlerinin daha düşük düzeylerde gerçekleşmesine ve bu suretle verimli alanlarda kullanılabilecek olan potansiyel kaynaklarda azalmaya sebebiyet verirken; diğer yandan da petrol gelirlerinin kamu harcamaları için kullanılmasına yol açarak bu kaynakların alternatif alanlara kanalize edilmesini imkânsız hale getirmektedir.

Petrol rezervlerinin bir gelir kaynağı olarak sonsuza kadar devam etmeyeceği gerçeği göz önünde bulundurulduğunda söz konusu ekonomik portrenin incelenen ülkeler açısından ileride arzu edilmeyen bazı ekonomik sonuçlara yol açabileceği öngörülebilir. Nitekim toplumlarda vergi bilincinin, vergi ahlakının ve vergi kültürünün yerleşmesi oldukça uzun zaman alan bir süreçtir ve vergi gelirlerinin kısa bir süre içerisinde yüksek seviyelere çıkarılması devletler açısından zorlu bir süreçtir.

Diğer yandan, bu ülkelerde vergi sisteminin göreli etkinsizliği vergi politikalarının da daha az etkin olmasına yol açmaktadır. Çünkü vergi politikasının varlığı her şeyden önce vergilerin mevcudiyetine bağlıdır. Dahası, bu ülkelerde vergilemenin gelişmemiş olması devletin genel ekonomi üzerindeki kayıt ve denetim mekanizmalarının da etkinsizliğine sebep olmaktadır.

İncelenen ülkeler gelişmekte olan ülkelerdir. Kalkınma süreçlerini henüz tamamlayamamışlardır. Kalkınma sürecinde ise, özellikle de fiziki ve beşeri sermayenin yetersz olduğu ülkelerde devletlerin rolü kilit bir öneme sahiptir. Bu ülkelerde fiziki sermaye kıtlığı olmamasına rağmen üretim alanında bilgi ve tecrübe eksikliği söz konusudur. $\mathrm{Bu}$, beşeri sermayenin yetersizliği anlamına gelmektedir. Söz konusu hal ise özel sektör yatırımlarının daha yüksek düzeylerde gerçekleşmesini engeller niteliktedir. Bu durum, devletlere iki ana rol yüklemektedir: (i) yatırım ve (ii) yönlendirme.

Bu anlamda, incelenen ülkelerde devletler öncelikle fiziki altyapı yatırımları ve beşerî sermayeye yönelik kamu harcamaları ile üretimi desteklemelidir.

Ayrıca, bu devletlerin etkin vergi politikaları ile yabancı doğrudan yatırımı ülkelere çekmesi durumunda hem yeni istihdam imkanları doğacak hem de bilgi ve teknoloji transferi süreci daha da hızlanacaktır. Fakat vergilemenin gelişmemiş olduğu bu ekonomilerde etkin bir vergi politikasının varlığından söz etmek de olanaksızdır. Çünkü yatırım carileri ve fiziki altyapı yatırımları vasıtası ile ekonomiye tekrar enjekte etmek üzere topladığı vergi miktarının ekonomik anlamda göreli önemi ve etkinliği oldukça düşük seviyelerdedir.

Sonuç itibariyle, incelenen bu ülkelerde vergi gelirlerine gereken önem verilmelidir. $\mathrm{Bu}$ doğrultuda, öncelikle, vergi gelirlerinin kamu gelirleri içindeki payının arttıılarak bu rakamın gelişmiş ekonomilerde gerçekleşen seviyelere yaklaştırılması gerekmektedir. Böylece bu devleler hem ek kamu geliri elde edecek hem de ekonomi politikaları doğrultusunda kullanılmak üzere etkin bir araç elde edeceklerdir. Tüm bu önlemler ise; yeni vergilerin koyulmasını, mevcut vergi sisteminin dizaynını, vergi tabanının genişletilmesini, vergi idarelerinin daha etkin işlemesine dönük politika önlemlerini gerektirmektedir. 


\section{SONUÇ}

Vergiler, günümüzün çoğu devleti için en önemli kamu geliri olma özelliğindedir. Bu nedenle; devletlerin sağlam bir kamu mali yönetime sahip olmaları ile etkin şekilde işleyen bir vergi sisteminin mevcudiyeti yakinen alakalıdır.

Öte yandan, vergiler birçok ülke için yalnızca önemli bir kamu geliri kalemi olmaktan ziyade, aynı zamanda önemli bir makroekonomik politika aracıdır. Etkin bir vergi politikası ve de iyi yönetilen bir vergilendirme sürecinin eşanlı mevcudiyetinin söz konusu olması durumunda devletler makroekonomik dinamiklerin çoğunu arzu edilen yönde şekillendirebilme konusunda güçlenirler.

OPEC üyesi Orta Doğu ülkelerinde vergi gelirlerinin toplam kamu gelirleri içerisindeki payının görece düşük olması onları önemli miktarlarda potansiyel bir kamu gelirinden mahrum bırakmaktadır. Bu ise bir yandan kamu gelirlerinin daha az düzeylerde gerçekleşmesine ve böylece verimli alanlarda kullanılabilecek olan potansiyel kaynaklarda azalmaya sebebiyet verirken, diğer yandan da petrol gelirlerinin kamu harcamaları için kullanılmasına yol açarak bu kaynakların alternatif alanlara kanalize edilmesini imkânsız hale getirmektedir.

Dahası, bu ülkelerde vergilerin göreli önemsizliği bu ülkeleri kilit bir ekonomi politikası aracından mahrum bırakarak devletlerin bağımsız ve daha etkin bir ekonomi politikası uygulamasını engellemektedir.

Bu ülkelerin acil eylem planı olarak vergi tabanını genişletmesi, vergi kalemlerini çeşitlendirmesi, vergi idarelerinin etkin şekilde işlemesine yönelik önlemler alması gibi eylemlerde bulunmaları gerekmektedir.

\section{ARAŞTIRMACILARIN KATKI ORANI BEYANI VE ÇIKAR ÇATIŞMASI BILDIRIMI}

Araştırmacılar herhangi bir çıkar çatışması bildirmemiştir.

Araştırmacılar makaleye ortak olarak katkıda bulunmuşlardır. 
KAYNAKÇA

Akan, Y., Arslan, I., ve Kaynak, S. (2008). Türkiye' de Ekonomik istikrarı Sağlamada Maliye Politikası Uygulamaları (Bir Ampirik Çalışma: 1980-2006), Sosyo-Ekonomi Dergisi, Ocak-Haziran 2008-1, 107-116.

Askari, H., Cumming, J. T., \& Glover, M. (1982). Taxation and Tax Policies in the Middle East, Butterworths Scientific.

Eğilmez, M., ve Kumcu, E. (2015). Ekonomi Politikası Teori ve Türkiye Uygulaması (20. Baskı) İstanbul: Remzi Kitabevi.

Gökçe, C. (2006), Vergi Kayıp ve Kaçaklarının Önlenmesinde Vergi Cennetleriyle Mücadele, Kıуı Bankacılığı ve Türkiye Örneği, Master Tezi, Süleyman Demirel Üniversitesi, Sosyal Bilimler Enstitüsü, Maliye Bölümü, Isparta.

Mankiw, N. G., (2003) "Macroeconomics", 5th Edition, Worth Publishers, New York and Basingstoke.

Musgrave, R., \& Musgrave, P., (1989). Public Finance in Theory And Practice (5th ed.). New York: McGraw-Hill Book Co.

Neumark, Fritz; McLure, Charles E. and Cox, Maria S. "Taxation". Encyclopedia Britannica, 10 Nov. 2020, https://www.britannica.com/topic/taxatio n. erişim tarihi 11.06.2021.

OECD (2021) https://data.oecd.org/tax/taxrevenue.htm, erişim tarihi: 08.06.2021.

OECD (2014) "Addressing the Tax Challenges of the Digital Economy" Oecd/G20 Base Erosion And Profit Shifting Project.

OPEC (2021a) https://www.opec.org/opec_web/ en/about_us/25.htm, erişim tarihi: 09.06.2021.

OPEC (2021b) https://www.opec.org/opec_web/ en/data_graphs/330.htm, erişim tarihi: 09.06.2021.
OPEC (2021c) https://asb.opec.org/data/ ASB_Data.php, erişim tarihi: 09.06.2021.

OPEC (2021d) https://www.opec.org/opec_web/ en/about_us/25.htm, erişim tarihi: 03.06.2021.

PWC (2021), https://taxsummaries.pwc.com/ saudi-arabia, erişim tarihi: 30.05.2021.

Şen, H.; Sağbaş, i. (2017). Vergi Teorisi ve Politikası, Kalkan Matbaacılık, Ankara.

Tekir, S. (1993). Vergi Teorisi, Anadolu Matbaacılık, İzmir.

Tinbergen, J. (1952). On the Theory of Economic Policy. North-Holland, Amsterdam.

Türk, i. (1989). Maliye Politikası, Türkmen Yayınları, İstanbul.

Üyümez, M. E., Pirdal, B. ve Gümüş, M. (2020) "Kripto Para Birimlerinin Vergilendirilmesi Üzerine Bir Değerlendirme", Mustafa Göktuğ Kaya \& Ersan Öz (Ed.), in Bilişim Çağında Vergi Hukuku (s. 195-206), Bursa: EKiN Basım Yayın Dağıtım, ISBN: 978-6257210-96-6. 